\title{
REVIEW OF THE TASKS OF FORMATION AND PROGRESS OF HUMAN RESOURCES IN THE SUSTAINABLE DEVELOPMENT STRATEGY OF UKRAINE IN THE LIGHT OF CENTRAL PLACE THEORY
}

\author{
Mykhailo Medvid' \\ National Academy of the National Guard of Ukraine, Ukraine \\ Oleksander Komisarov ${ }^{2}$ \\ Kyiv Faculty of the National Academy of the National Guard of Ukraine, Ukraine \\ Olga Merdova ${ }^{3}$ \\ Donetsk Law Institute Ministry of Internal Affairs of Ukraine, Ukraine
}

\begin{abstract}
The purpose of the article is to describe an economic background of the formation of the strategy of sustainable development by means of central place theory, in particular, a target of the progress of human resources. In this article, there were considered the elements of SWOT-analysis in the strategy of sustainable development of Ukraine, and by this consequence, a strong side through such a positive influence of an internal environment as the population of the country was determined. Only the population is available to resist the main negative influence of inner and outside surroundings on Ukraine: to form necessary and replace an existing management; to shift intercivilisational direction towards the border of Ukraine. There was also made a statistical analysis of result of process of forming and development of human resources in Ukraine (the dynamics of population size, its natural movement, and the level of unemployment) and, as a sequence, we can argue the absence of accordance of real conditions of the socialeconomic conditions by those people who are available to certain types of works, necessary expert knowledge and its improvement and use of acquired capability of human resources during the creation of welfare in considering of standing changes during the activities. It leads to migration, and that's why there is a risk for sustainable development. And it leads to losses of active-age population, facilitates the reduction of births. By the statistics of migration processes and processes of forming of run and supplies of educational services by the countries, we validate the hypothesis about central place theory, which is reasonable to use in practice not only in regard to inhabited localities and also in regard to countries. Practical importance of the scientific research results lies in reconsideration of the tasks of forming and developing of human resources in strategy of sustainable development of Ukraine in the light of central place theory, which is important for successful social-economic development of the state and concurs to screen out the factors, which prevent a social-economic development, facilitates the development and following improvement of regulatory framework. In view of the stated above, the scientific researchers in this area are relevant and timely within the period of search for the priorities of national economic policy. Methodology. Methodological backgrounds of research formation of standing development of Ukraine are scaled by means of complex scientific knowledge, which let to consider this problem as a complicated phenomenon. On the background of studying about internal and outside surroundings of the country (SWOT-analysis), central place theory, and others scientific approaches, an idea of standing development of Ukraine is a complicated systematic category.
\end{abstract}

Key words: sustainable development strategy, formation and progress of human resources, migration, demand and supply of educational services, central place theory.

JEL Classification: J4, J6

Corresponding author:

${ }^{1}$ Training and Methods Centre; Methods Department, National Academy of the National Guard of Ukraine.

E-mail: medvidmm@ukr.net

${ }^{2}$ Department of Military-Special Branches of Sciences, Kyiv Faculty of the National Academy of the National Guard of Ukraine.

E-mail: tsp1dduvs@gmail.com

${ }^{3}$ Department of Administrative and Legal Disciplines, Donetsk Law Institute Ministry of Internal Affairs of Ukraine.

E-mail: olga.merdova@ukr.net 


\section{Introduction}

The United Nations Millennium Declaration, approved in 2000 by 189 countries on the Millennium Summit of UNO, determined the Millennium Development Goals, all-embracing frames of values, principles, and key factors of development to 2015. After elaborating all-round frames of MDGs in many countries, MDGs were brought to effect in accordance with national situations. Ukraine joined the Millennium Declaration and pledged itself to achieve MDGs to 2015. In September 2015 during the 70th session of the General Assembly took place the Summit of UNO about sustainable development and reception of the Post-2015 Development Agenda, where were ratified new guideline of development. The main document of the Summit was "Transforming our world: the 2030 Agenda for Sustainable Development” in which 17 goals of development and 169 tasks were confirmed. Ukraine as a member of the UN joined to a global process of constant development. For establishing strategic frames of national development of Ukraine to 2030 in accordance with the principle "None can be left aside" was initiated an exclusive process of adaptation to MDGs. Every global aim was considered in accordance with the specificity of national development (sustainable development goals of Ukraine). On 15 September 2017, the Government of Ukraine presented the National Report "Sustainable Development Goals: Ukraine".

On minds of authors, some goals (in particular, 10 Reduction of inequality inside the countries and among them) cannot be achieved. Their contents contradict to central place theory, which is used in practice not only to inhabited localities and also to countries. A special attention needs reconsideration of tasks such as formation and progress of human resources.

In view of the noted above, the purpose of this publication is the reconsideration of tasks of formation and progress of human resources in accordance with sustainable development of Ukraine through the prism of central place theory, especially tasks with goals 8 "Gradual, all-side comprehensive and sustainable economic growth, full and productive employment for everyone" and 4 "Providing an all-side fair qualitative education and supporting a possibility for studying during the whole life for everybody", that would be aimed at the prevention of devastating development of the threats to national security.

\section{Elements of SWOT-analysis according to a strategy of development of Ukraine}

The sustainable development is a general conception concerning the necessity of balance to satisfy human needs and protect interests of future generations and to take into account their need of safe and healthy environment. The Brundtland Commission formed a determination of sustainable development in its report; this is a development which satisfies the needs of today's generation without damage for future generations to satisfy their own needs (Butlin, 1989).

The strategy of sustainable development determines a goal, direction, road map, basic priorities and indicators of conditions of development and formation of Ukraine such as defence, social-economic, political-lawful. For its development, there should be implemented a detailed analysis of inside and outside environment of the state (SWOT-analysis). It was partly displayed in a previous study (Medvid \& Zvieriev, 2017). But it should be started with the fundamental negative influence (Table 1).

Table 1

The fundamental negative influence of inside and outside environment in Ukraine

\begin{tabular}{|l|l|l|}
\hline & Positive influence & Negative influence \\
\hline \multirow{2}{*}{$\begin{array}{l}\text { Inside } \\
\text { environment }\end{array}$} & Strengths & $\begin{array}{l}\text { Weaknesses } \\
1 . \text { The absence of necessary } \\
\text { management } \\
\end{array}$ \\
\hline & $\ldots$ & $\ldots$ \\
Outside & Opportunities & $\begin{array}{l}\text { Threats } \\
\text { environment }\end{array}$ \\
& $\ldots$ & guideline \\
& & $\ldots$ \\
\hline
\end{tabular}

Ukraine is the Intercivilisational guideline and it's the main threat to its development. Guideline "frontier" (border) is the territory between two societies. It's a transitional zone as a rule which is weakly integrated into state structures and has a dynamic coordination as often hostile cultures. In this case, it means European and Russian, Islamic civilizations (Juricek, 1966).

The vulnerable side of Ukraine is the absence of strong management. The untimely decision about the integration into one or another system of community defence was a mistake for Ukraine, which led to the annexation of the Crimea and war on the Eastern of the country (Figure 1).

Despite that Ukraine has already determined its course of integration into the system of CS of NATO accordingly to existing measures, the annexation of the Crimea and the war on East of the country don't allow making a decision.

The main threat of development of Ukraine may be partially neutralized by moving it away to its eastern or western border. Despite trying to fulfil the first scenario via inadequate abilities (SWOT-analysis), which are formed by means of outside environment, can be changed to the contrary.

Here should be considered the possibilities of mentioned civilizations, which goals are the contrary.

The strong side is a positive influence of inside surrounding and this is its population. Only the population can counteract the main fundamental negative influence of inside and outside surrounding 


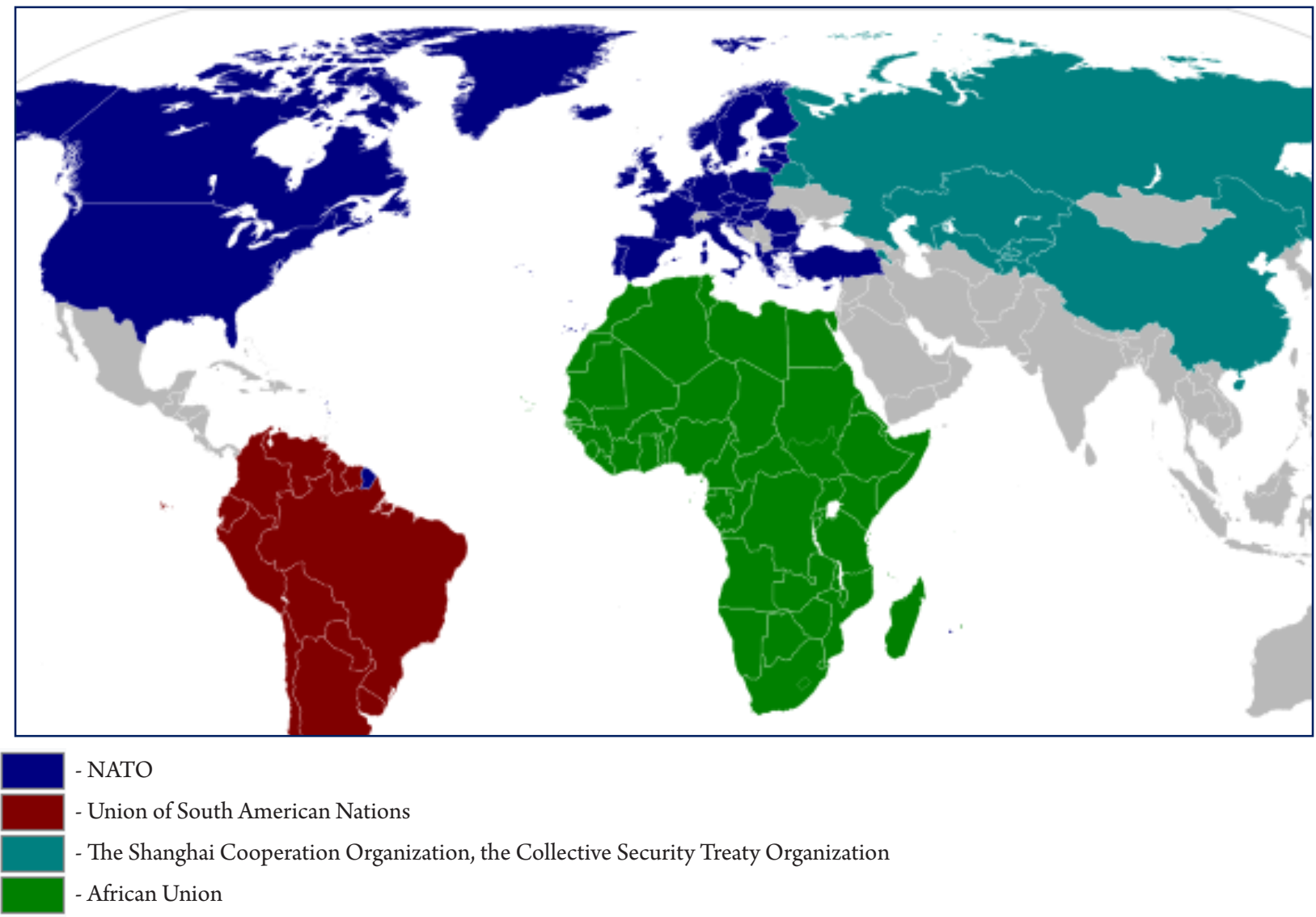

Figure 1. Ukraine between systems of collective security (CS)

on Ukraine: to form a strong and replace an existing management; to move intercivilisational frontier to its border. That's why in the strategy of social development, it is necessary to review the tasks of formation and progress of human resources.

\section{Statistical analysis of findings of formation and progress of human resources in Ukraine}

The formation and progress of human resources, its supplying real social-economic conditions of formation by people who are able to a certain work and competencies for its improvement and use of acquired capabilities of human resources to create a welfare by taking into account constantly changes during their activity (Medvid, 2015).

On the $1^{\text {st }}$ of January 2018 , the number of population was 42,22 million. For 15 years, it was descended on 5,62 million. By taking into consideration such a tendency, we may prognosticate that on $1^{\text {st }}$ of January 2023 it will calculate 40,83 million (Figure 2).

What can characterize such a dynamic of a decrease in the population of Ukraine? It may happen by natural decreasing of the population (Figure 3), which number was 3,13 million during the researches. Following the prognosis, if the number of births and a number of deaths will stay invariably natural decreasing of Ukrainians will change on the natural increase in 2027.

The next factor is a migration movement of population. During the research, the number of migrants was more than a number of immigrants on 2,13 million people. To the migrants that can be enlisted the people from Crimea, the city of Sevastopol and a number of people from the zone of ATO.

Following the prognosis coefficients of births, length of life and migration stay invariable so in 2050 the population of Ukraine will be 32 million citizens.

Labour migration is influenced by the level of unemployment, which comes up to a mark of $10 \%$ (Figure 4). This point is liminal, which may have unexpected consequences for society and needs the acceptance of special programs to provide an employment of population.

Decreasing demands on educational services among Ukrainians in Ukraine but growths among foreigners are a result of such dynamics. For 15 years, the number of foreign students has tripled. 66310 foreign students study at Ukrainian educational establishments from 147 countries around the world (16.4\% - from India, 11.3\% - from Azerbaijan, 8.8\% - Morocco, 6.7\% from Turkmenistan), (Ukrainian State Centre For International Education, 2018). Before the crisis, 


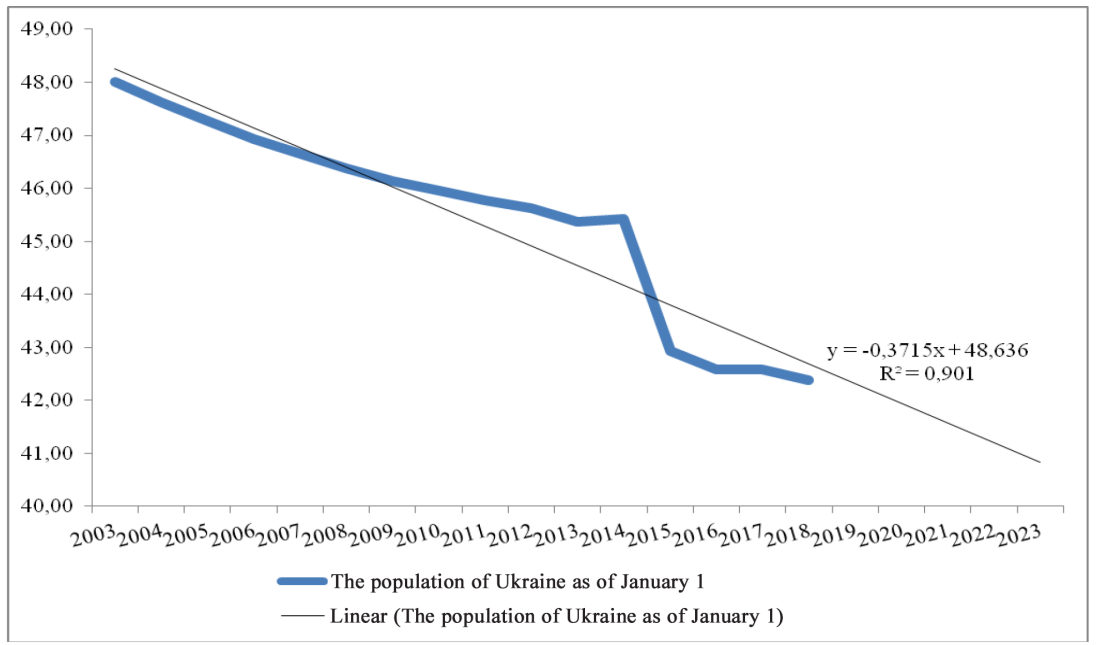

Figure 2. The number of population of Ukraine, million

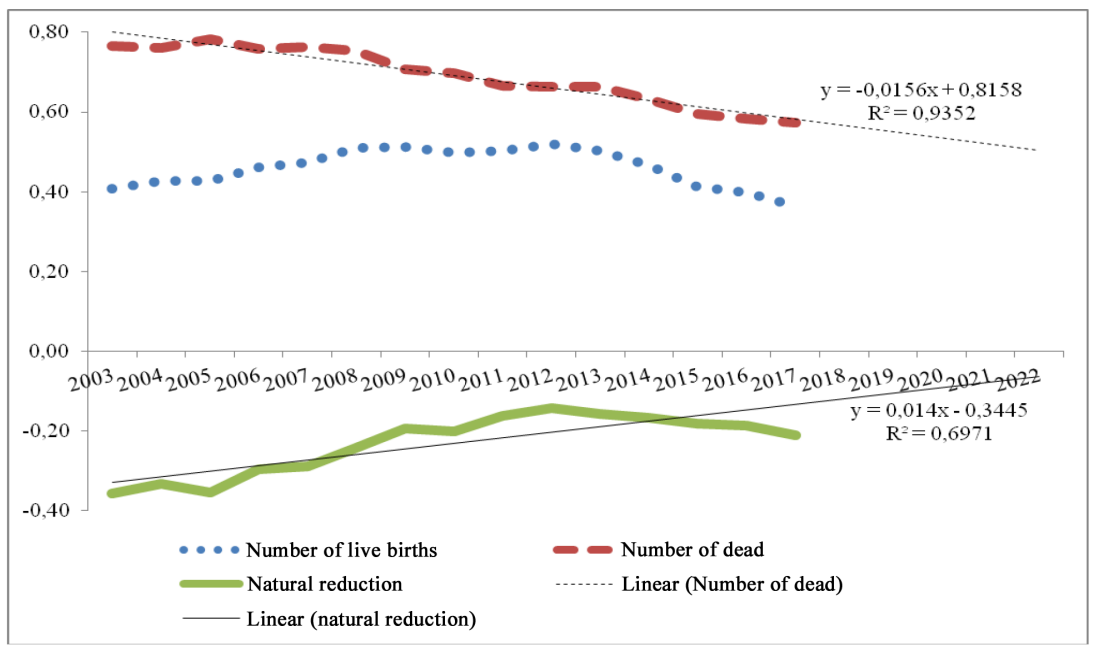

Figure 3. The natural movement of population of Ukraine, million

Annotation: The pictures were designed by using findings of official website of State Statistics Service of Ukraine http://ukrstat.gov.ua.

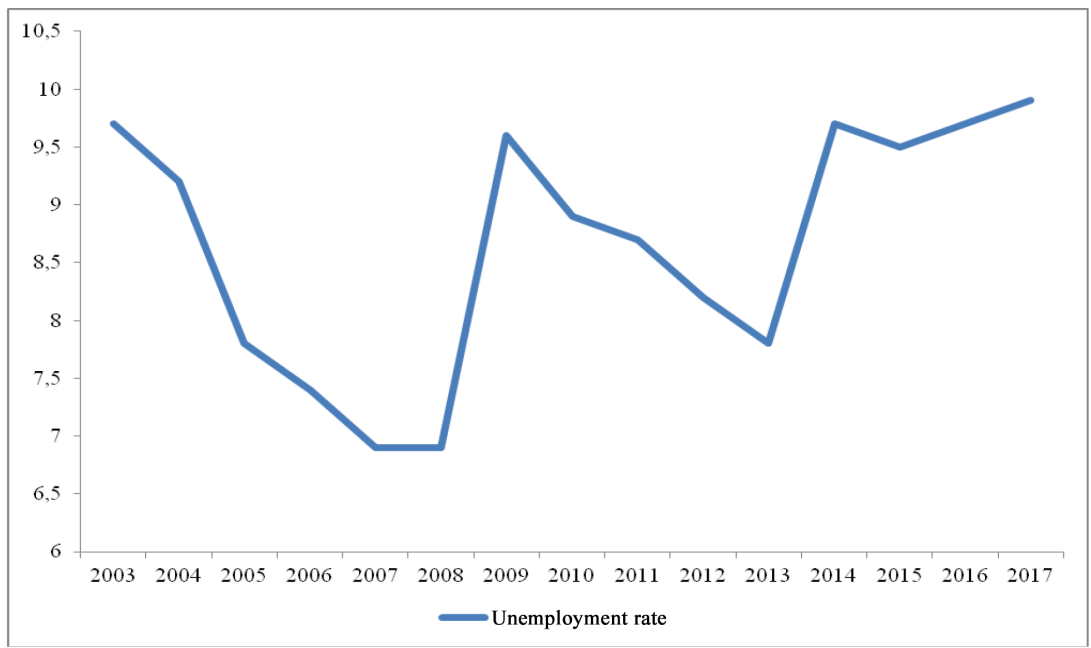

Figure 4. The unemployment rate of able-bodied population, $\%$

Annotation: The pictures were designed by using findings of official website of State Statistics Service of Ukraine http://ukrstat.gov.ua. 
the number of foreign students grew up stably and in 2013 reached almost 70 thousand. The most popular are medical and pharmacological kinds of education. Almost all foreign students are citizens of CIS-member countries. However, because of war on the east of Ukraine, the arrival of educational migrants began to decrease (Migration in Ukraine, facts and figures, 2016).

Following the UNESCO records, during the period 2000-2012 the number of Ukrainian students who study abroad increased in more than 4 times and sums 37 thousand. Especially their number was high in countries connected with labour migration. Following the researches of annual monitoring the number of Ukrainian citizens who study at foreign universities on daily form based on findings of the analytic centre CEDOS (includes 34 countries around the world), during 2013/2014 academic year, 47724 Ukrainians were studying abroad. The largest number of students studied in Poland (15 ths), Germany (9 ths), Russia (6 ths), Canada (2 ths), Czech Republic (2ths), Italy (1,9 ths), the USA (1,5 ths), Spain (1,4 ths), France (1,3 ths), Great Britain (1 ths) (Migration in Ukraine: facts and figures, 2016).

Therefore, following the results of statistical analysis by means of findings of process of progress and formation of human resources in Ukraine, we may affirm the absence of accordance between reality to socio-economic conditions of forming the necessary competencies and their improvement and using all necessary human resources during the process of creation of welfares in accordance with changes during the activities by people who are able to work. It leads to migration and has a risk for a constant development. The losses of able-bodied people and decreasing of births are the result of migration.

\section{Formation and progress of human resources and central place theory}

A central place theory is an aggregate of main statements, which explain a number, size, and location of inhabited localities of the city system. The theory was created in 1933 by German geographer Walter Christaller who affirmed that inhabited localities function as central places that provide services in adjoined districts (Christaller, 1967).

The central places are economic centres, which serve themselves and supply goods and services to its districts, form the net of inhabited localities with free access to the objects of human services and moving between them. Hierarchy is a system among inhabited localities, which allows determining an inhabited locality (with increasing of the hierarchy) and supplies more services to localities, which are under them in Table.

A theory of central places may be used not only for inhabited localities and also to countries. We may check up this hypothesis on world's map with social progress index of countries (Social Progress Index, 2017). A social index progress is a general index of social and ecologic indicators, which shows three aspects of social progress: the main needs of humans, backgrounds of wealth, and possibilities. Figure 4 shows graphically a theoretical formation of basic migration route of Ukrainians to European countries by means of their social progress.

The central place for Ukraine takes Germany. It consists of Czech Republic, Slovakia, Poland and others, which make a similar net with free access to human services and moving inside the net. In a given example the hierarchy concurs with the classification of groups of indexes of social process in countries: it's very high, high, upper, upper-intermediate.

In this hierarchy, we'll study the process of formation and progress of human resources, which is characterized on basic migration route and a way of supplying of educational services (Figure 5, 6).

The number of Ukrainians who live in the EU growths up constantly. In 2015, there was 905,2 ths. It was $6 \%$ of backward countries on the territory of EU. The largest number of Ukrainians were in Italy (238 ths.), Poland (336 ths), Germany (112 ths), Czech Republic (113 ths) and Spain (84 ths). In 2015 Ukrainians got 493 official remittances for living in EU-countries that was 1,5 times higher than in 2014. The vast majority was given in Poland (87\%). Practically all of them were short-dated (3-12 months) and were registered for season work.

A work activity was the main purpose of the arrival of Ukrainians to the EU. There were registered $76 \%$ of permits to work; it was the third part of all backward countries. Following the researches made by MOM in 2014-2015, there were approximately 700 thousand Ukrainians abroad (Migration in Ukraine, 2016).

Statistics about migration processes, the formation of processes of demand and propositions of educational services by countries may confirm the hypothesis that the central places applied in practice in relation to settlements and countries.

\section{Review of tasks formation and progress of human resources in the strategy of development of Ukraine through the prism of central place theory}

Let us consider strategies development of Ukraine, their content 4 - "Providing comprehensive, qualitative education and encouraging learning opportunities throughout life for all", 8 - "Assistance to economic growth, full and productive employment, worthy work for all" (Sustainable development goals: Ukraine).

Goal 4 - "Providing comprehensive qualitative education and encourage learning opportunities throughout life for all". About higher education, it is mentioned only in one task 4.4 - "To increase the quality of higher education 


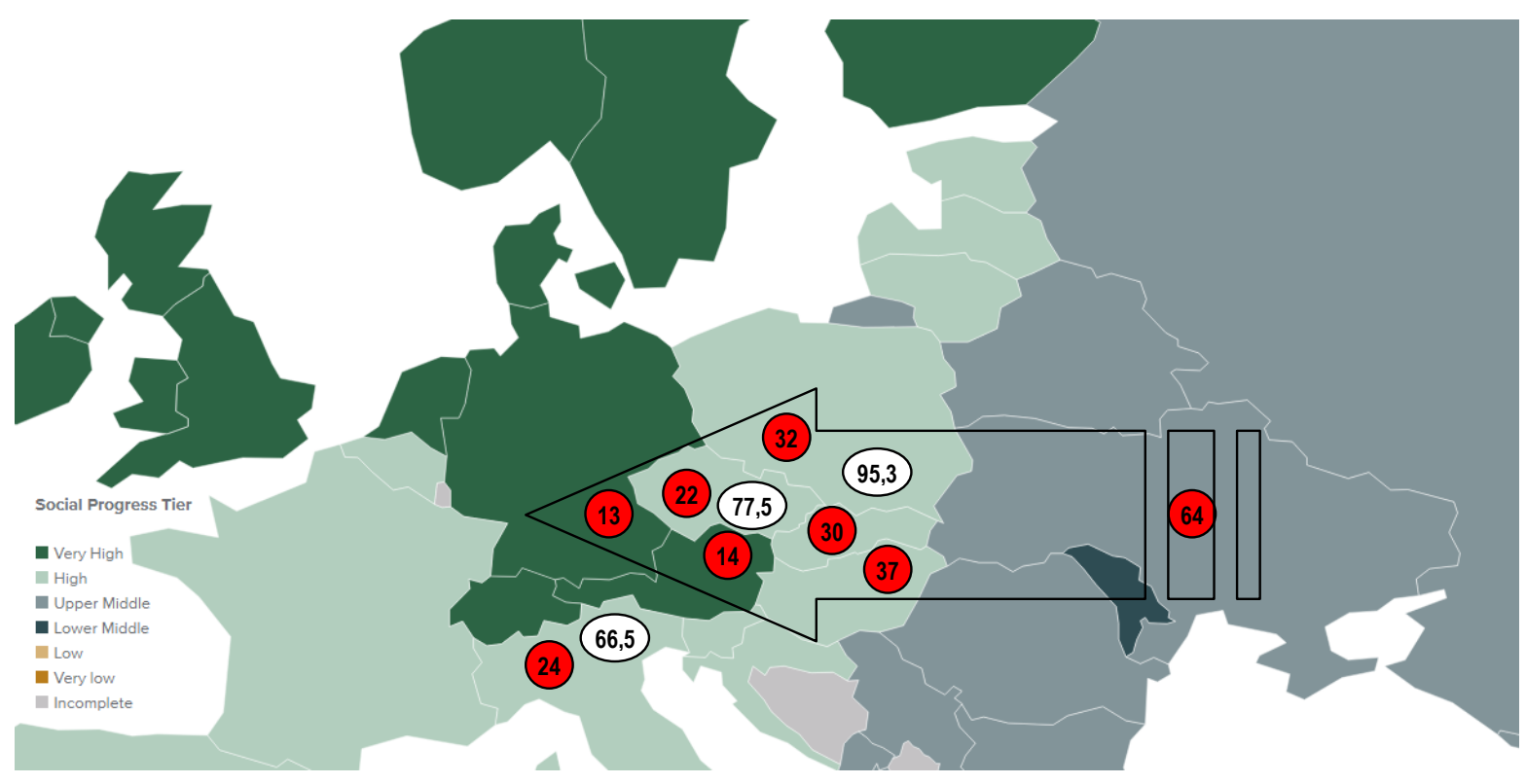

- index of the country according to social progress

Figure 5. A theoretic formation of migration route of Ukrainians to European countries by means of their social process Annotation: The figure was made by using statistic records of Social Progress Index https://www.socialprogressindex.com

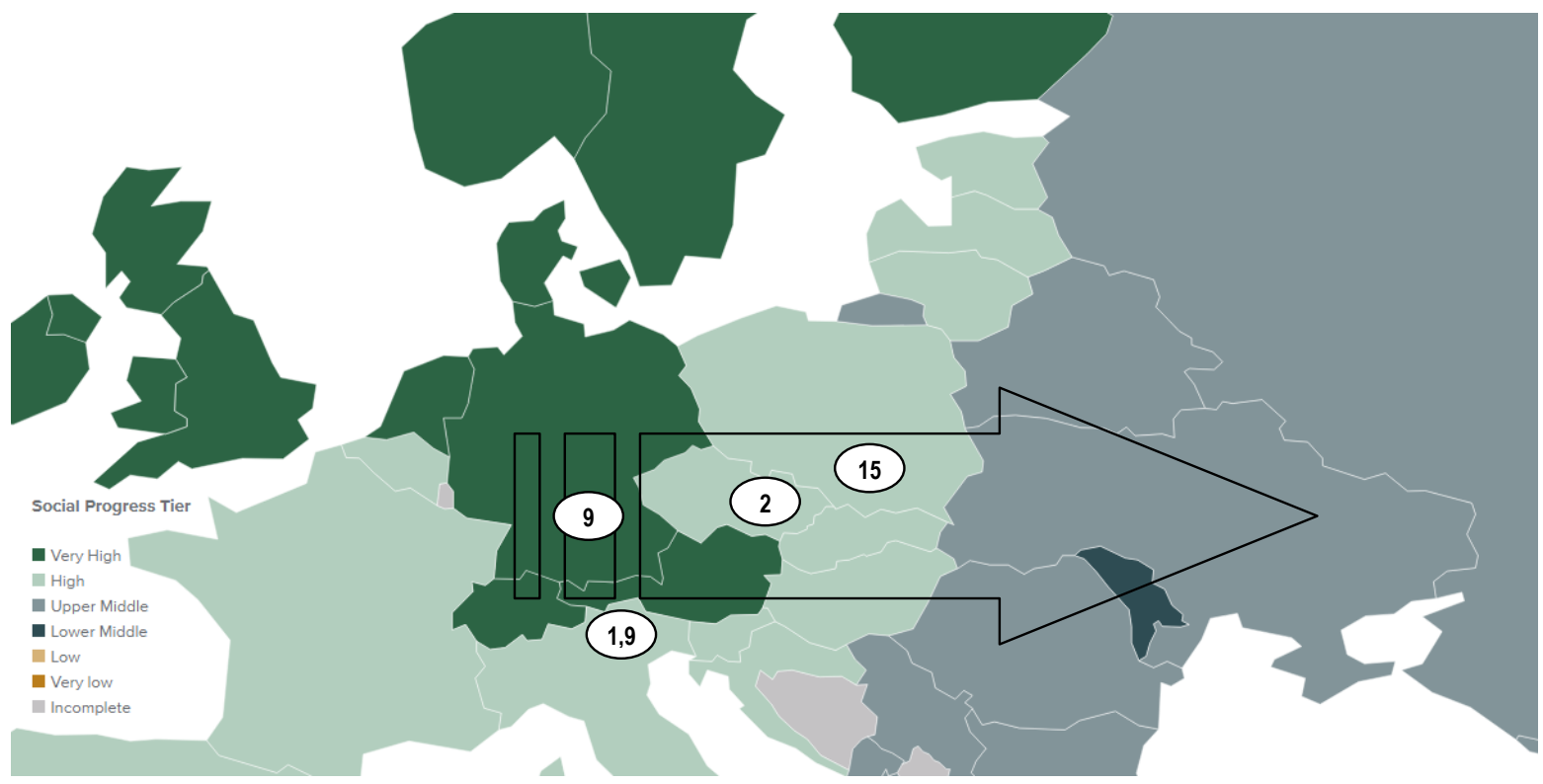

$>-$ the main route of supplying educational services

(15) - the main countries which propose successfully educational services for Ukrainians and the number of students, ths.

Figure 6. Formation of proposals of educational services by educational establishment of European countries for Ukraine 
and provide its communication with science, promote the formation in country cities of education and science." About promoting the formation of cities of education and science in the country, it is not correct, considering the above analysis. The Ukrainian population is turning to the formation of demand for educational services in those in which they will be able to continue to work in the future. Considering an increase in the level of unemployment in Ukraine, mentioned tendency will become stronger. Unemployed will become also scientific workers with scientific grades because of decreasing of demands on educational services in Ukraine. It's a pity that in national report of 2017, there is no explanation about the necessity for increasing the number of university cities from 7 to 14 .

Goal 8 - "Assistance for economic growth, full and productive employment, worthy work for all." An interesting task is 8.4 "Reduce the share of young people who do not work, do not study, and do not acquire professional skills" and an appropriate indicator of change in education from 17.7 to $15.5 \%$. There is no need to try here, due to migration indicator value to the 2030 year may be smaller. You must agree with an indicator of realization of goal 8.1.4 "Ukraine's place in the rating by the innovation index." In the national report of 2017, the change in its value is projected from 64 to 40 in 2013. However, if such a situation does not change the position of Poland, Czech Republic, Italy, then the situation in Ukraine will not be much better. All tasks and indicators of this goal are correct, however, as well.
Returning to the elements of SWOT, in our opinion, one of the positive effects of the internal environment is higher education institutions, scientific and pedagogical workers of Ukraine, and the environment is in demand of citizen of the countries with an index of social progress is lower than in Ukraine for educational services in Ukraine. Developing this direction can increase revenues of Ukraine, save the scientific potential of the state.

\section{Conclusions}

The scientific novelty of research is an approach in the formation of development in Ukraine through the prism of central place theory. It's proved that a theory of central places may be used in practice not only regarding inhabited localities and also concerning to countries. The striking example of it is a process of creation of human resources. By possessing a results of statistical analysis of mentioned process in Ukraine (the dynamics of population size, its natural movement, and the level of unemployment), we made a conclusion that there is no suitability among a real life and equal socialeconomic conditions of forming by able-bodied people all necessary competencies and their improvement and also the using of acquired human capabilities by process of creation of welfare, which threats sustainable development. It's offered to review tasks of formation and progress of human resources by sustainable development strategy of Ukraine by means of central place theory.

\section{References:}

Tsili Staloho Rozvytku: Ukraina - natsionalna dopovid [Sustainable Development Goals: Ukraine - national report] (2017). Retrieved, March, 2018, from: http://un.org.ua/images/SDGs_NationalReportUA_Web_1.pdf

Butlin, J. (1989) Our common future. By World commission on environment and development, Journal of International Development, 1 (2), pp. 284-287.

Medvid M., Zvieriev M. (2017) Possibilities to provide development of social benefits of military and nuclear security, Perspectives - journal on economic issue, 2, pp. 28-40.

Juricek J. (1966) American Usage of the Word «Frontier» from Colonial Times to Frederick Jackson Turner, Proceedings of the American Philosophical Society, 100, pp. 110-34.

Medvid M. (2015) Metodolohiia formuvannia i rozvytku liudskykh resursiv dlia vykorystannia u sluzhbovo-boiovii diialnosti [Methodology of forming up and development of human resources in combat and everyday service] (Doctor degree in Economic sciences, speciality 08.00.07 - demography, labor economics, social economics and politics), Kharkiv: Simon Kuznets Kharkiv National University of Economics. - 584 p.

Ofitsiinyi veb-sait Derzhavnoi sluzhby statystyky Ukrainy [Official website of State Statistics Service of Ukraine] (2018). Retrieved, March, 2018, from: http://ukrstat.gov.ua.

Ofitsiinyi veb-sait Ukrainskoho derzhavnoho tsentru mizhnarodnoi osvity [Official website of Ukrainian National Centre for International Education] (2018). Retrieved, March, 2018, from: http://studyinukraine.gov.ua/uk/ zhittya-v-ukraini/inozemni-studenti-v-ukraini/

Mihratsiia v Ukraini: fakty i tsyfry [Migration in Ukraine: facts and figures] (2016), Kyiv: International Organization for Migration. - 31 p.

Christaller W. (1967) Central Places in Southern Germany / translated by C.W. Baskin. - NY: Englewood Cliffs. -230 p.

Social Progress Index (2018) Retrieved, March, 2018, from: https://www.socialprogressindex.com 